\title{
Bats as potential suppressors of multiple agricultural pests : A case study from Madagascar
}

\section{Kemp, James}

2019-01-01

Kemp , J , López-Baucells , A, Rocha , R , Wangensteen, O S , Andriatafika , Z E , Nair , A

\& Cabeza , M 2019 , ' Bats as potential suppressors of multiple agricultural pests : A case

study from Madagascar ' , Agriculture, Ecosystems \& Environment, vol. 269 , pp. 88-96 . https://doi.org/10.1016/j.ag

http://hdl.handle.net/10138/311518

https://doi.org/10.1016/j.agee.2018.09.027

cc_by_nc_nd

acceptedVersion

Downloaded from Helda, University of Helsinki institutional repository.

This is an electronic reprint of the original article.

This reprint may differ from the original in pagination and typographic detail.

Please cite the original version. 
Highlights:

- Malagasy bats select rice producing agricultural areas for foraging, potentially acting as important pest suppressors.

- Open space and edge space bats benefit the most by the conversion of forest to rice fields.

- Several economically important agricultural pests and disease vectors were detected in bat faecal samples.

- Promoting and conserving bat populations in agricultural landscapes might increase agricultural yields. 
1 Bats as potential suppressors of multiple agricultural pests: a case study from

2 Madagascar

3 James Kemp ${ }^{1}$, Adrià López-Baucells ${ }^{1,2,3}$, Ricardo Rocha ${ }^{3,4}$, Owen S. Wangensteen ${ }^{5}$, Zo $4 \quad$ Andriatafika ${ }^{3,6}$, Abhilash Nair $^{3}$, Mar Cabeza $^{3}$

1. Center for Ecology, Evolution and Environmental Changes (cE3c), Faculdade de Ciências da Universidade de Lisboa, 1749-016 Lisboa (Portugal).

7

2. Granollers Museum of Natural Sciences, 08402 Granollers, Catalonia (Spain).

3. Global Change and Conservation Lab, Helsinki Institute of Sustainability Science, Faculty of Biological and Environmental Science, University of Helsinki, FI-00014 Helsinki (Finland)

4. Conservation Science Group, Department of Zoology, University of Cambridge, Cambridge, CB2 3EJ (UK)

5. Norwegian College of Fishery Science, University of Troms $\varnothing$ The Arctic University of Norway

6. Institute of Science and Technics of the Environment (ISTE), University of Fianarantsoa, BP 1264 Fianarantsoa (Madagascar).

\section{Corresponding author: James Kemp (jamesrussellkemp@gmail.com)}

Keywords: Chiroptera, Acoustics, Agriculture, Rice, Ecosystem services, Crop pests, Pest control, Metabarcoding 
The conversion of natural habitats to agriculture is one of the main drivers of biotic change.

Madagascar is no exception and land-use change, mostly driven by slash-and-burn agriculture, is impacting the island's exceptional biodiversity. Although most species are negatively affected by agricultural expansion, some, such as synanthropic bats, are capable of exploring newly available resources and benefit from man-made agricultural ecosystems. As bats are known predators of agricultural pests it seems possible that Malagasy bats may be preferentially foraging within agricultural areas and therefore provide important pest suppression services. To investigate the potential role of bats as pest suppressors, we conducted acoustic surveys of insectivorous bats in and around Ranomafana National Park, Madagascar, during November and December 2015. We surveyed five landcover types: irrigated rice, hillside rice, secondary vegetation, forest fragment and continuous forest. 9,569 bat passes from a regional assemblage of 19 species were recorded. In parallel, we collected faeces from the six most common bat species to detect insect pest species in their diet using DNA metabarcoding. Total bat activity was higher over rice fields when compared to forest and bats belonging to the open space and edge space sonotypes were the most benefited by the conversion of forest to hillside and irrigated rice. Two economically important rice pests were detected in the faecal samples collected - the paddy swarming armyworm Spodoptera mauritia was detected in Mops leucogaster samples while the grass webworm Herpetogramma licarsisalis was detected from Mormopterus jugularis and Miniopterus majori samples. Other crops pests detected included the sugarcane cicada Yanga guttulata, the macadamia nut-borer Thaumatotibia batrachopa and the sober tabby Ericeia inangulata (a pest of citrus fruits). Samples from all bat species also contained reads from important insect disease vectors. In light of our results we argue that Malagasy insectivorous bats have 
bat populations as they may contribute to higher agricultural yields and promote sustainable livelihoods.

\section{Introduction}

The pervasive conversion of forests for food production is a conspicuous symbol of the Anthropocene (Malhi, 2017). Large swaths of forest have already been cleared for agriculture and the encroachment of natural ecosystems is due to continue as human populations and food demand continue to rise (Giam, 2017). Madagascar holds a unique ensemble of ecosystems and wildlife that is almost unmatched in its biological uniqueness (Goodman and Benstead, 2005). However, despite its high level of endemism and species diversity, Madagascar's forests continue to face one of the highest rates of conversion in the world with approximately $1 \%$ of the island's forest cover being cleared each year (Rasolofoson et al., 2015; Eklund et al., 2016; Vieilledent et al., 2018). While most Malagasy biodiversity is adversely affected by agriculture-driven habitat modification, some 'winner' species benefit from habitat modification and increase their abundance in agricultural areas. Several of these are insectivorous birds (Martin et al., 2012; Rocha et al., 2015) and bats (López-Baucells et al., 2017b) that through the suppression of agricultural pests can provide valuable ecosystem services to local populations (Karp and Daily 2014; Maas et al. 2015).

Rice (Oryza spp.) is one of the most important staple food crops worldwide (Muthayya et al., 2014). It is the main crop cultivated by Malagasy subsistence farmers (Kari and KorhonenKurki, 2013) throughout the island, and as in numerous other high-biodiversity regions across the tropics, much of the ongoing deforestation is due to agricultural expansion for rice production (McConnell et al., 2004; Neudert et al., 2017). Such a high dependency on rice creates problems when yields are affected by climatic events or pest outbreaks (Harvey et al., 2014). Insect rice pests are known to cause severe damage to rice crop yields (Oerke, 2006). 
Rice crop losses are predominantly caused by Lepidopteran stem borers found across several families such as the Noctuidae, Pyralidae, Tortricidae or Geometridae (Nwilene et al., 2013).

Modern day farming techniques incorporate Integrated Pest Management (IPM) to control pest populations (Stenberg, 2017). However, many small-holder farmers in sub-Saharan Africa are unable to access IPM techniques due to lack of financial capital or expertise (Parsa et al., 2014). A sustainable and low cost method to aid pest control and reduce crop losses is through biological control (Bommarco et al., 2013; Naranjo et al., 2015). Biological control, as part of a wider application of integrated pest management practices, can involve insectivorous bats, and has already been proven effective for pecan and rice farms in the USA and Catalonia (Brown et al., 2015; Puig-Montserrat et al., 2015). Multiple lines of evidence support that aerial hawking insectivorous bats provide valuable agricultural pest control services in both temperate and tropical regions (Boyles et al., 2011; Karp and Daily, 2014; Wanger et al., 2014; Brown et al., 2015; Russo et al., 2018). For instance, in the Mediterranean the soprano pipistrelle Pipistrellus pygmaeus was found to suppress rice borer moth Chilo suppressalis populations through opportunistic foraging (Puig-Montserrat et al., 2015). However, to date most research on tropical bat predation services has focussed on coffee and cacao agroecosystems (Maas et al., 2016), with limited research targeting rice (Wanger et al., 2014). One notable exception comes from Thailand where it was estimated that predation of white backed planthoppers Sogathella furcifera by wrinkle-lipped bats Tadarida plicata prevents rice crop losses valued at $>1.2$ million USD (or $>26,000$ rice meals) each year (Wanger et al., 2014).

Numerous bat species (particularly of the Molossidae and Vespertilionidae families) are known to coexist synanthropically by exploring newly available resources. These bat families have been shown to feed on pests (Brown et al., 2015) and to select crops as preferred foraging areas especially during insect pest outbreaks (Lehmkuhl Noer et al., 2012; Taylor et 
al., 2013a; Davidai et al., 2015). In fact, bats tend to select foraging areas based upon the resources available (Ancillotto et al., 2017), which makes them excellent pest suppressors during seasonal insect pest outbreaks.

Large colonies of molossid bats roost in buildings across Madagascar (Razafindrakoto et al., 2010; López-Baucells et al., 2017b). However, any potential predation services provided by these colonies are yet to be explored. Forty-two species of insectivorous bats occur in Madagascar, with several species occurring more frequently in anthropogenic landscapes as opposed to forest habitats (Randrianandrianina et al., 2006; Rakotoarivelo et al., 2007). In general, most studies have focused on the dry western region (Goodman et al., 2005; Kofoky et al., 2006; Bambini et al., 2010; Racey et al., 2010; Fernández-Llamazares et al., 2018) as opposed to the humid eastern zone (Randrianandrianina et al., 2006) and only a few studies have tackled habitat selection while none have addressed the potential pest suppressor role in agricultural areas.

The DNA metabarcoding of bat faecal pellets can offer valuable insights into the dietary preferences of bats and their potential role as pest suppressors (Bohmann et al., 2014; Swift et al., 2018). Recent diet analyses of multiple bat species have detected a wide range of arthropods in bat populations (Galan et al., 2017) including several economically important pest species (Taylor et al., 2017).

Here, we combine bioacoustics and DNA metabarcoding to investigate if Malagasy insectivorous bats are foraging within the island's agricultural matrix and if they are consuming important pest species. Specifically, we address the following questions:

i) How does total bat activity, species (or species-group) activity and assemblage composition change across a rice-dominated agroecosystem landscape? We hypothesise that due to higher insect availability some bats will be more active 
over rice fields compared to forested sites. We also predict a clear shift in assemblage composition from open to closed landcover types.

ii) Which species (or species-groups) are more common within the agricultural matrix? We predict that synanthropic molossids will be particularly abundant in rice fields but we still anticipate some forest associated species to forage outside the forest border.

iii) Are bats roosting within the agricultural matrix predating on agricultural insect pests? We expect bats to predate mainly on moths and beetles and we predict that several of these will be agricultural pests of rice and other crops.

\section{Methods}

\subsection{Study area}

Fieldwork was conducted primarily in the peripheral zone surrounding the Ranomafana National Park (RNP) $\left(21^{\circ} 16^{\prime} \mathrm{S}, 4^{\circ} 20^{\prime} \mathrm{E}\right)$. The peripheral zone comprises over 160 villages with a population in excess of 50,000 in an area of approximately $500 \mathrm{~km}^{2}$ (Kari and Korhonen-Kurki, 2013). Agricultural communities in the region, like many throughout Madagascar, cultivate rice through slash-and-burn agriculture (tavy) and irrigated paddies (Peters, 1998; Brooks et al., 2009). The RNP is located between the central highlands and the eastern lowlands and is of particular ecological and economic interest due to its high biodiversity and watershed protection role.

\subsection{Bat surveys}

Bats were surveyed from November to December 2015 in 54 sites in and around RNP (Fig. 1). Sites were clustered around seven villages (Kelilalina, Tsaratanana, Mangevo, Andriamamovoka, Amboasary, Mandriandry and Tolongoina) and were classified into five landcover categories: irrigated rice fields $(n=12)$, hillside rice fields $(n=8)$, secondary 
vegetation i.e. fallow agricultural land of mixed successional vegetation $(n=11)$, forest

147 fragment ( $n=9)$ and continuous forest in $\mathrm{RNP}(n=15)$ (for landcover images and description see supplementary materials Fig. A.1.). Bat activity was recorded using SongMeter SM2BAT+ and SM3 autonomous bat detectors (Wildlife Acoustics, Concord, MA, USA). Detectors were secured to a tree at approximately $1.5 \mathrm{~m}$ with external SMX-II omnidirectional microphones (Wildlife Acoustics, Concord, MA, USA). Detectors were set to record calls continuously from 18:00 until 06:00 for three consecutive nights at each locality. Bat activity was sampled for 1,956 hours across a total of 147 detector-nights of sampling effort. Detectors were set with a $384 \mathrm{kHz}$ sample rate, $12 \mathrm{kHz}$ digital high pass filter, $18 \mathrm{~dB}$ trigger level, microphone bias off, and $36 \mathrm{~dB}$ gain. We used a $1.0 \mathrm{~s}$ trigger window minimum to capture calls prior to the initial trigger.

\subsection{Bioacoustic analysis}

Recordings were manually classified using Kaleidoscope software version 3.1.7 (Wildlife Acoustics, Concord, MA, USA). We defined a bat pass as a recording of five seconds maximum with at least two pulses with more than $20 \mathrm{~dB}$ of difference between the background noise and bat call (Appel et al., 2017) Call sequences were manually identified to species level or left as mixed species groups, or sonotypes, where it was not possible to clearly assign a call to a particular species (Torrent et al., 2018). Call sequences were also identified as feeding buzzes (specific echolocation sequence that a bat uses as it pursues and subsequently catches its prey). We used the frequency of maximum energy or peak frequency $(\mathrm{kHz})$, the start and ending frequencies $(\mathrm{kHz})$, the duration $(\mathrm{ms})$ and the call shape to identify or group species from the existing literature and our own release calls (Fenton et al., 1980;

Russ and Bennett, 2001; Kofoky et al., 2009; Goodman et al., 2011; Goodman et al., 2015).

Our analysis included a total of 11 sonotypes from the families Emballonuridae, 
Hipposideridae, Molossidae, Miniopteridae, Myzopodidae and Vespertilionidae. Five sonotypes were classified to species level and the remaining six into sonotype groups (Table 1).

\section{\#Table 1 approximately here\#}

\subsection{Faecal sample collection}

Mist-nets were used to capture bats at roosts in five villages in the RNP area (for sampling details see López-Baucells et al., 2017). Three caves were inspected and surveyed with mistnetting outside of the emergence point (for Miniopterus spp. and Myotis goudoti). Bats were measured, weighed and identified using keys (Russ and Bennett, 2001; Goodman, 2011). Bat capture and handling was conducted following guidelines approved by the American Society of Mammalogists (Sikes et al., 2011). We kept the bats in cloth bags for an hour until defecation occurred. Faecal pellets were labelled and stored in $2 \mathrm{ml}$ tubes in $95 \%$ ethanol and stored in a cool dry space. Of the 322 bats caught, we collected faecal samples from 150 bats. Fifty-eight faecal samples from six species (Chaerephon atsinanana, Mops leucostigma, Mormopterus jugularis, Myotis goudoti, Miniopterus manavi, Miniopterus majori) were used for the diet analysis.

\subsection{DNA extraction and PCR amplification}

The DNA was extracted from the faecal samples using the Norgen Stool Kit following instructions provided by the manufacturers (Norgen Biotek Corp.). Amplification of DNA from the faeces was achieved using the Leray-XT PCR primer set (Wangensteen et al., 2018b), a highly degenerated primer set targeting a 313-bp fragment of the mitochondrial cytochrome c. oxidase subunit I (COI) region. The mlCOIintF-XT primer (5'GGWACWRGWTGRACWITITAYCCYCC-3') was used as forward primer. This modified version (Wangensteen et al., 2018b) of the mlCOIintF primer (Leray et al., 2013) included 
two extra degenerate bases (equimolar mixtures of two different bases at a given position) and two inosine nucleotides to enhance its eukaryotic universality. The reverse primer was jgHCO2198 (5'-TAIACYTCIGGRTGICCRAARAAYCA-3';(Geller et al., 2013)). The Leray fragment has already been successfully applied to the characterisation of both marine fish gut contents (Leray et al., 2013), marine invertebrates (Siegenthaler et al., 2018) and terrestrial arthropods (Macías-Hernández et al., 2018). A single-PCR step using primers with attached eight-base oligo-tags (Coissac et al., 2012) was used to label different samples in a multiplexed library; moreover a variable number (2, 3 or 4$)$ of fully degenerate positions (Ns) was added at the beginning of each primer, in order to increase variability of the amplicon sequences (Guardiola et al., 2015) .The PCR mix recipe included $10 \mu$ AmpliTaq gold 360 master mix (Applied Biosystems), $3.2 \mu \mathrm{g}$ Bovine Serum Albumin (Thermo-Scientific), $1 \mu 1$ of each of the $5 \mu \mathrm{M}$ forward and reverse tagged-primers, $5.84 \mu \mathrm{l}$ water and $2 \mu \mathrm{l}$ extracted DNA template $(\sim 5 \mathrm{ng} \mu \mathrm{l}-1)$. The PCR profile included an initial denaturing step of $95^{\circ} \mathrm{C}$ for $10 \mathrm{~min}, 35$ cycles of $94{ }^{\circ} \mathrm{C}$ for $1 \mathrm{~min}, 45^{\circ} \mathrm{C}$ for $1 \mathrm{~min}$ and $72{ }^{\circ} \mathrm{C}$ for $1 \mathrm{~min}$ and a final extension step of $72{ }^{\circ} \mathrm{C}$ for 5 minutes. After a quality check of all amplicons by electrophoresis, the tagged PCR products (including a negative control) were pooled into a multiplexed sample pool and purified using MinElute columns (Qiagen). An Illumina library was subsequently built from these pools, using the NextFlex PCR-free library preparation kit (BIOO Scientific). The library was sequenced on an Illumina MiSeq platform using v3 chemistry (2x250 bp paired-ends), as part of a multiplexed run including ten other unrelated libraries.

\subsection{Bioinformatic analyses}

Bioinformatic analyses were performed using the OBITools metabarcoding software suite (Boyer et al., 2016). Read quality assessment was performed with FastQC and only pairedend reads with phred quality score $>40$ was retained. Demultiplexing and primer removal 
were achieved using ngsfilter. Obigrep was applied to select all aligned reads with a length between 303-323 bp and without ambiguous bases. Obiuniq was used to dereplicate the reads and the uchime-denovo algorithm (Edgar et al., 2011) implemented in VSEARCH (Rognes et $a l ., 2016)$ was used to remove chimeric sequences. Amplicon clustering was performed using the SWARM 2.0 algorithm (Mahé et al., 2015) with a distance value of d=13, which offers a conservative solution to the high variability of the COI gene (Siegenthaler et al., 2018). Taxonomic assignment of the representative sequences for each molecular operational taxonomic unit (MOTU) was performed using the ecotag algorithm (Boyer et al., 2016), using a local reference database (Wangensteen et al., 2018b) containing filtered COI sequences retrieved from the BOLD database (Ratnasingham and Hebert, 2007) and the EMBL repository (Kulikova et al., 2004). This algorithm uses a phylogenetic approach to assign sequences to the most reliable monophyletic unit, so that sequences are assigned to different taxonomic ranks, depending on the density of the reference database. The data was refined by removing contaminations of marine origin (originated by tag-switching from other multiplexed libraries in the sequencing run). A minimum abundance filter of 5 total reads was used to avoid false positives and low frequency noise (De Barba et al., 2014; Wangensteen and Turon, 2017). This pipeline, with little variations, has been previously used for analysing metabarcoding data for the same COI marker in a variety of systems (e.g. Wangensteen and Turon, 2017; Macías-Hernández et al., 2018; Siegenthaler et al., 2018; Wangensteen et al., 2018a; Wangensteen et al., 2018b). The resulting data has been deposited on Mendeley Data ([dataset] Kemp et al., 2018)

\subsection{Statistical analysis}

Bat activity was defined as the total number of bat passes per night from all species as well as for each sonotype (Torrent et al., 2018). As appropriate for count data, negative binomial or Poisson generalized linear mixed models (GLMMs) with a log link function were used to 
model the relationship between bat activity and landcover type (continuous forest, forest fragments, secondary vegetation, hillside rice and irrigated rice) (Burnham and Anderson, 2003). Species with less than 300 recordings were not used in the analysis due to a lack of model convergence. Since preliminary analyses suggested that the count data were overdispersed, we accounted for this overdispersion by using a Poisson or negative binomial regression in glmer or glmmADMB and adding a random intercept of "Site" nested within "Location" (Bates, 2010).

252 Numbers of bat passes were positively correlated with feeding buzzes (Table A.1). We therefore only used the larger bat passes dataset for modelling as a proxy for feeding activity (Torrent et al., 2018). Moran's I test showed that there is no residual spatial autocorrelation between sites (Table A.2). The difference in assemblage structure between landcover types was analysed using the analysis of dissimilarity test adonis. It was visualised through a nonmetric multidimensional scaling (NMDS), based on a Bray-Curtis dissimilarity matrix, using sonotype activity data per site. We analysed and presented the data using $\mathrm{R}$ statistical software 3.4.1 (R Development Core Team, 2017) with the packages: tidyverse (Wickham, 2016), lme4 (Bates et al., 2014), glmmADMB (Skaug et al., 2015) and vegan (Oksanen et al., 2013).

The relative abundance of MOTU reads for prey items (excluding predator reads and normalized to 10,000 total prey reads per sample) was calculated for all prey MOTUs. The relative abundances per faecal sample for all prey MOTUs were then averaged per bat species. We then grouped the MOTU sequences by arthropod orders and highlighted the pest and disease transmitting insect species, alongside any species or genera that we suspected to have a potential pest status. 


\section{Results}

269

270

271

272

273

274

275

276

277

278

279

280

281

282

283

284

285

286

287

288

289

290

291

\subsection{Bat activity}

We recorded a total of 9,569 bat passes, of which 1,643 (17\%) were identified to species level (Hipposideros commersoni, M. manavi, M. goudoti, Myzopoda aurita, Paraemballonura atrata), 2,261 (24\%) were identified to sonotypes of two species (Miniopterus gleni/M. majori, Scotophilus robustus/M. gleni, S. robustus/M. jugularis, Otomops madagascariensis/Tadarida fulminans), and 5,665 (60\%) were attributed to sonotypes Molossidae 1 (Mo1: C. atsinanana, M. leucostigma, M. jugularis, Taphozous mauritianus) and Vespertilionidae/Miniopteridae 1 (VMi1: M. gleni, M. majori, M. manavi, Miniopterus soroculus, Neoromicia matroka, Pipistrellus hesperidus, Pipistrellus raceyi). In total 1,013 feeding buzzes were recorded, with Mo1 accounting for 389 (38\%) of feeding buzzes, VMi1 for $334(33 \%)$ and P. atrata for $102(10 \%)$.

Bat activity was highest in hillside rice with a mean of 197 passes/night and more than double that of the next landcover type with more bat activity - irrigated rice at 89 passes/night (Table 2). Overall bat activity in both types of rice field, hillside and irrigated, was higher than activity levels in continuous forest (Table A.3). According to pairwise comparisons (Table A.4), total bat activity over hillside rice was higher than in continuous forest $(p<0.01)$ and forest fragments $(\mathrm{p}<0.05)$ whereas activity in irrigated rice was only higher than continuous forest $(\mathrm{p}<0.01)$

In hillside and irrigated rice, Mo1, VMi1, M. goudoti and M. gleni/M. majori, had significantly higher activity compared to continuous forest while O. madagascariensis/T. fulminans was higher in hillside rice compared to continuous forest. In continuous forest and forest fragments, $P$. atrata and $M$. goudoti had the highest mean bat passes/night, respectively (Fig. 2). 
\#Table 2 approximately here\#

\#Figure 2 approximately here\#

\subsection{Assemblage composition}

Assemblage composition varied between landcover type (adonis: $\mathrm{r}^{2}=0.253 ; \mathrm{p}=0.001$ ). This was corroborated by the NMDS ordination which revealed distinct patterns of dissimilarities in assemblage composition between the five landcover classes (Fig. 3). The NMDS had a final stress value of 0.12 conveying a good representation of the data along the represented dimensions.

\#Figure 3 approximately here\#

\subsection{Presence of insect pests in faecal samples (DNA metabarcoding)}

We obtained a total number of 655,205 MOTU reads from all samples. $43.5 \%(285,978)$ of the reads were attributed to bats while $5.3 \%(34,599)$ of the reads were assigned to arthropods. Overall, when looking at the insect orders found in the faecal samples, the highest average relative abundance of MOTU reads found were of Coleoptera, Lepidoptera, Ephemeroptera, Diptera and Hemiptera (Table 3). All the bats species sampled fed on, at least, 11-13 orders of arthropods.

\section{\#Table 3 approximately here\#}

In 58 bat faecal samples we found six known pest species, seven insect vectors of human diseases and 17 potential pest taxa (Table A.5). Of the known agricultural pests found in the faecal samples, two economically important rice pest species were found - the paddy swarming caterpillar Spodoptera mauritia in M. leucogaster and the grass webworm Herpetogramma licarsisalis in M. jugularis and M. majori. Other crops pests detected were: the black twig borer Xyleborus ferrugineus a pest of coffee; the sugarcane cicada Yanga guttulata; the macadamia nut-borer Thaumatotibia batrachopa and the sober tabby Ericeia inangulata a pest of citrus fruits. Potential pest species and genera, from the order 
Lepidoptera, were found in all bat species. In particular: Mythimna sp. - a genus containing the rice armyworm Mythimna unipuncta; Emmalocera sp. - a genus containing a sugarcane root borer Emmalocera depressella; and Cydia choleropa - a sister species of the codling moth Cydia pomonella a pest of apples and pears.

\section{Discussion}

Large colonies of, predominantly, molossid, vespertillionid and miniopterid bats, were found to be preferentially selecting the rice fields surrounding the RNP. Six species of bats were shown to have fed upon economically important insect pests such as the paddy swarming caterpillar (Spodoptera mauritia) and the Grass webworm (Herpetogramma licarsisalis). In agreement with Puig-montserrat et al. (2011) and Wanger et al. (2014) insectivorous bats, particularly molossids, are likely to be preferentially selecting rice fields for foraging and feeding upon rice crops pests and other economically important insects.

Bat activity across landcover types.

The highest overall mean activity was found in hillside rice followed by irrigated rice and secondary vegetation (Table 2). Hillside rice has markedly lower yields compared to lowland irrigated rice. Water and nutrient run-off impact the growth of upland rice. A lack of water and nutrient retention in the rice crop makes it more susceptible to insect pest infestations. This may be one reason why we recorded the highest activity in hillside rice. However, it is also possible that there was an altitudinal detection bias as hillside rice and secondary vegetation sites were on open hillsides with little vegetation and facing large valleys (Collins and Jones, 2009). Both sites, however, were found at similar altitudes and had markedly different results (Table 2, Table A.3). Irrigated rice sites, on the other hand, are found at the bottom of valleys. Despite the possible altitudinal bias, activity within irrigated rice was the second highest of the landcover types (Table 2, Table A.3). Intensive rice agriculture harbours high densities of insect pests which provide an excellent resource for insectivorous 
bats. Insects form swarms, especially tympanic moths (Noctuidae, Crambidae and Pyralidae), during mating and emergence, which bats are able to opportunistically prey upon (McCracken et al., 2012; Malmqvist et al., 2018).

The open space group, Mo1, was the most active overall and over hillside rice (Figure 2, Table 2). This suggests that open-space aerial hawkers are important agents of pest suppression in the rice-dominated landscape surrounding the RNP and potentially throughout much of Madagascar's agroecosystems. Further research and action is required to improve the knowledge of bats dietary preferences, both temporally and spatially. The reputation of these bats among local communities needs to be improved, especially as they form large colonies in public buildings (López-Baucells et al., 2017b).

The results conform to the notion that molossids (in addition to Taphozous mauritianus), which are open-space aerial hawkers, commute and forage at higher altitudes than other families (Lee and McCracken, 2002; McCracken et al., 2008; Taylor et al., 2013b). Open space foragers have a high wing loading ratio (fast flight; low manoeuvrability) which suggests that they do not use cluttered sites and this explains their low detection in forested areas (Schnitzler and Kalko, 2001).

The sonotype VMi1, comprised of three vespertilionids and three miniopterids, was found to be the most active in irrigated rice fields and the second most active overall (Figure 2, Table 2). The species in this sonotype forage as edge-space aerial-hawkers (Verboom and Huitema, 1997; Taylor et al., 2013b). The mosaic of vegetation and fruit trees, rivers and streams, paths, terraces and anthropomorphic structures within the vicinity of the rice fields may provide this group with the required heterogeneity or "edge" habitat to forage (Monck-Whipp et al., 2018). This is important for the contextualization of our results as edge-space foragers 
are known to predate upon insect pests within agroecosystems (Taylor et al., 2013a; Taylor et al., 2013b; Brown et al., 2015; Puig-Montserrat et al., 2015)

The edge-clutter species, Myotis goudoti and Paraemballonura atrata, were previously captured in forest in the same region as our study (Goodman et al., 2014). We recorded both species at relatively high levels in irrigated rice, forest fragments and continuous forest sites. Although post hoc tests showed no significant differences, this activity shows that these species are selecting lowland irrigated rice and forest for foraging. The NMDS plots show that both species are strongly associated with forest sites (Fig. 3). NMDS axis 2 shows $P$. atrata is more associated with rice fields than M. goudoti. The fact that these edge-clutter species, P. atrata and M. goudoti, switch between open and closed sites highlights the importance of retaining forest nearby for roost provision and maintaining bat populations. The paucity of available roosts for bats in rice dominated landscapes is certainly an issue and one that requires addressing as a sustainable solution to crop losses. Installing bat houses and improving landscape heterogeneity are ways to address the lack of suitable roosts available (Flaquer et al., 2006; Lindell et al., 2018; Monck-Whipp et al., 2018).

Additionally, we recorded two charismatic, endemic and difficult to catch species Myzopoda aurita and Hipposideros commersoni. The eastern sucker-footed bat Myzopoda aurita was recorded in hillside and irrigated rice and in secondary vegetation (Table 2). This species roosts in the furled-up leaves of the traveller's palm Ravenala madagascariensis which can grow in open areas of vegetation or forest. Commersoni's horseshoe bat Hipposideros commersoni is the largest insectivorous bat in Madagascar, listed as Near Threatened (Andriafidison, 2008), and it was mainly recorded in hillside rice (Table 2). The echolocation of Hipposideros commersoni (high duty cycle echolocation) is extremely efficient for hunting in cluttered spaces. The bat may be roosting in the remnant forests and foraging in the adjacent hillside rice. The rarity of both species might limit their 
predation services but their high association with forest habitat qualifies them as good indicator taxa for the evaluation of habitat disturbance.

392

As expected, from the NMDS plots, the assemblage composition in the landscape shows that there was a turnover of species and sonotypes (Fig. 3). One can see a gradient from irrigated rice to continuous forest, from left to right. The open space foragers (Mo1 and $O$. madagascariensis/T. fulminans) occupy the left side of NMDS axis 1 while the clutter and edge-space foragers $(M$. goudoti and $P$. atrata) occupy the right side of the plot, illustrating the foraging preferences of the aforementioned guilds (Schnitzler and Kalko, 2001). Hillside rice and secondary vegetation almost entirely overlap which illustrates the similarity of these sites in terms of species assemblage.

\section{Diet analysis and implications of bat foraging behaviour}

The DNA metabarcoding results illustrate that insectivorous bats feed on a wide range of prey including a number of economically important insect pest species that affect a range of crops in addition to insect disease vectors (see supplementary materials Table A.5.). The results of this study, therefore, show the potential role of insectivorous bats in supressing economically important insects in agricultural landscapes.

We found that the sonotypes that were preferentially selecting rice fields were also the most important contributors to pest suppression in rice fields. For example, M. leucogaster and $M$. jugularis from the Mo1 sonotype were found to have fed upon the rice pests Spodoptera mauritia and Herpetogramma licarsisalis, respectively (Table A.5). Greater pest suppression leads to greater yields and less reliance upon slash and burn agriculture, or tavy (Styger et al., 2007). This form of agriculture is environmentally damaging and encroaches upon forests when fallow lands are no longer fertile. Forest fragments still offer valuable refuges for certain species, yet insectivorous bats generally prefer rice fields for foraging. By identifying 
the most active sonotypes and how they change across different land-uses we can begin to understand the level of pest suppression that bats provide to agricultural landscapes.

It is important to note that the fieldwork only spanned a short amount of time (approximately three days per locality). The research therefore does not reflect the seasonal and spatial variation of bat diets nor do the results intentionally follow peaks in insect populations. Additionally, although we have identified bat predation on predatory arthropods that can potentially contribute to the suppression of agricultural pests (e.g. spiders - order Araneae were identified in the diet of $M$. goudoti; Table 3) we did not explore the effects of intra-guild predation on herbivorous arthropods. Since most Malagasy bats are predominantly aerial feeders we anticipated that bat predation on non-flying arthropods would be limited. We suggest that future research should try to investigate the effects of intra-guild predation and any potential cascading effects on the abundance of agricultural pests and on rice yield. Furthermore, despite the fact that our study focussed on a rice-dominated agroecosystem, it is

427 important to note that the pests of other crops found in bat faeces illustrates the global potential of bats as pest suppressors. Further research quantifying the role of bats as pest suppressors in Madagascar is urgently needed as they: receive little protection from Malagasy legislation; fall under game species regulations i.e. they are not actively protected; many are data deficient; and there is little appreciation of their role in ecosystem services (Racey et al., 2010).

\section{Conclusions}

Deforestation and habitat loss due to agricultural expansion are the primary driver of biodiversity loss in Madagascar. The need for agricultural expansion to compensate for crop losses is exacerbated by climatic extremes and insect pest outbreaks. We found that Malagasy insectivorous bats have the potential to suppress these outbreaks as they predate upon insect 
pests. Therefore, retaining and maximising bat populations across the island's agricultural landscapes can contribute to higher agricultural yields and help promote sustainable livelihoods. Provision of artificial roosts such as bat-boxes (Puig-Montserrat et al., 2015; López-Baucells et al., 2017a) and increased landscape heterogeneity is an important consideration for agricultural and conservation planning, specifically for open and edgeforagers. Since some cave-dwelling bat species (i.e. Miniopterus manavi, Miniopterus majori, and Myotis goudoti) were also predating on insect pests, appropriate conservation legislation and cave protection initiatives (i.e. regulation of the harvesting of guano and cave tourism) are essential to keep their populations stable. Further research and action is required to improve the knowledge of bat dietary preferences, following pest outbreaks both temporally and spatially, while improving the reputation of bats among local communities.

\section{Acknowledgements}

450 We thank Georges Razafindrakoto, Eric Marcel Temba, Kristian Forbes and Tafita Tojosoa 451 Rakotoarimanana for fieldwork and logistical assistance, and MICET and Centre ValBio staff for their hospitality and logistical support. We also thank the Department of Biosciences, University of Helsinki for supporting the RESPECT field course. Madagascar National Parks and the "Ministere de l'Environnement de l'ecologie et des forests" (Département de Biologie Animale, DBA) provided the research permits to capture bat specimens within the study area (293/15/MEEMF/SG/DGF/DAPT/SCBT). This work was supported by the Portuguese Foundation for Science and Technology under Grant PD/BD/52597/2014 for ALB, 318 SFRH/BD/80488/2011 for RR and PD/BD/114363/2016 to JK. MC is financially 
461 Figure 1. Map of sampling sites within and surrounding the Ranomafana National Park,

462 Madagascar.

463

464

465

466

467

468

469

470

471

472

473

474

475

476

477

478

479

480

481

Figure 2. Mean bat activity per night per sonotype (>300 passes) for each landcover type, with standard errors. See Table 1 for sonotype abbreviations.

Figure 3. NMDS plot showing community assemblage of sonotypes (in text) relative to sampling sites (coloured dots - corresponding to landcover type). See Table 1 for sonotype abbreviations.

Table 1. List of species known to occur in the region incorporating Ranomafana National Park with sonotypes created from mean peak frequency ranges from the existing literature.

Table 2. Mean bat passes $( \pm \mathrm{SD})$ per night per sonotype across each landcover type.

Significant differences to continuous forest from generalised linear mixed models highlighted in bold.

Table 3. Average relative abundance of MOTU reads per 10,000 reads for six bat species (number of samples in brackets) grouped by arthropod order. See Table A.5 for insect pest and disease vector species and genera.

\section{References}

Ancillotto, L., Ariano, A., Nardone, V., Budinski, I., Rydell, J., Russo, D., 2017. Effects of free-ranging cattle and landscape complexity on bat foraging: Implications for bat conservation and livestock management. Agric., Ecosyst. Environ. 241, 54-61

Andriafidison, D., Cardiff, S.G., Goodman, S.M., Hutson, A.M., Jenkins, R.K.B., Kofoky, A.F., Racey, P.A., Ranivo, J., Ratrimomanarivo, F.H. and Razafimanahaka, H.J. , 2008. 
Hipposideros commersoni. In: IUCN (Ed.), The IUCN Red List of Threatened Species 2008.http://dx.doi.org/10.2305/IUCN.UK.2008.RLTS.T10120A3168011.en.

Appel, G., López-Baucells, A., Magnusson, W.E., Bobrowiec, P.E.D., 2017. Aerial insectivorous bat activity in relation to moonlight intensity. Mamm. Biol. 85, 37 46.https://doi.org/10.1016/j.mambio.2016.11.005

Bambini, L., Kofoky, A., Mbohoahy, T., Ralisata, M., Manjoazy, T., Hosken, D.J., Jenkins, R.K., 2010. Do bats need trees? Habitat use of two Malagasy hipposiderid bats Triaenops furculus and T. menamena in the dry Southwest. Hystrix 22.https://doi.org/10.4404/Hystrix$22.1-4467$

Bates, D., Maechler, M., Bolker, B., Walker, S., 2014. lme4: Linear mixed-effects models using Eigen and S4. R package version 1

Bates, D.M., 2010. lme4: Mixed-effects modeling with R. Springer New York Bohmann, K., Evans, A., Gilbert, M.T.P., Carvalho, G.R., Creer, S., Knapp, M., Douglas, W.Y., De Bruyn, M., 2014. Environmental DNA for wildlife biology and biodiversity monitoring. Trends Ecol. Evol. 29, 358-367.https://doi.org/10.1016/j.tree.2014.04.003 Bommarco, R., Kleijn, D., Potts, S.G., 2013. Ecological intensification: harnessing ecosystem services for food security. Trends Ecol. Evol. 28, 230238.https://doi.org/10.1016/j.tree.2012.10.012

Boyer, F., Mercier, C., Bonin, A., Le Bras, Y., Taberlet, P., Coissac, E., 2016. obitools: a unix-inspired software package for DNA metabarcoding. Mol. Ecol. Resour. 16, 176182.https://doi.org/10.1111/1755-0998.12428

Boyles, J.G., Cryan, P.M., McCracken, G.F., Kunz, T.H., 2011. Economic importance of bats in agriculture. Science 332, 41-42 
Brooks, C.P., Holmes, C., Kramer, K., Barnett, B., Keitt, T.H., 2009. The role of demography and markets in determining deforestation rates near Ranomafana National Park, Madagascar.

Brown, V.A., de Torrez, E.B., McCracken, G.F., 2015. Crop pests eaten by bats in organic pecan orchards. Crop Protect. 67, 66-71.https://doi.org/10.1016/j.cropro.2014.09.011 Burnham, K., Anderson, D., 2003. Information and likelihood theory: a basis for model selection and inference. In: Burnham, K.P., Anderson, D.R. (Eds.), Model selection and multimodel inference: a practical information-theoretic approach. Springer Science \& Business Media, pp. 49-97.

Coissac, E., Riaz, T., Puillandre, N., 2012. Bioinformatic challenges for DNA metabarcoding of plants and animals. Mol. Ecol. 21, 1834-1847.https://doi.org/10.1111/j.1365294X.2012.05550.x

Collins, J., Jones, G., 2009. Differences in bat activity in relation to bat detector height: implications for bat surveys at proposed windfarm sites. Acta Chiropt. 11, 343350.https://doi.org/10.3161/150811009X485576

Davidai, N., Westbrook, J.K., Lessard, J.-P., Hallam, T.G., McCracken, G.F., 2015. The importance of natural habitats to Brazilian free-tailed bats in intensive agricultural landscapes in the Winter Garden region of Texas, United States. Biol. Conserv. 190, 107114.https://doi.org/10.1016/j.biocon.2015.05.015

De Barba, M., Miquel, C., Boyer, F., Mercier, C., Rioux, D., Coissac, E., Taberlet, P., 2014. DNA metabarcoding multiplexing and validation of data accuracy for diet assessment: application to omnivorous diet. Mol. Ecol. Resour. 14, 306-323.https://doi.org/10.1111/1755- 
Edgar, R.C., Haas, B.J., Clemente, J.C., Quince, C., Knight, R., 2011. UCHIME improves sensitivity and speed of chimera detection. Bioinformatics 27, 21942200.https://doi.org/10.1093/bioinformatics/btr381

Eklund, J., Blanchet, F.G., Nyman, J., Rocha, R., Virtanen, T., Cabeza, M., 2016. Contrasting spatial and temporal trends of protected area effectiveness in mitigating deforestation in Madagascar. Biol. Conserv. 203, 290-297.https://doi.org/10.1016/j.biocon.2016.09.033 Fenton, M., Bell, G., Thomas, D., 1980. Echolocation and feeding behaviour of Taphozous mauritianus (Chiroptera: Emballonuridae). Can. J. Zool. 58, 17741777.https://doi.org/10.1139/z80-244

Fernández-Llamazares, Á., López-Baucells, A., Rocha, R., Andriamitandrina, S.F., Andriatafika, Z.E., Burgas, D., Temba, E.M., Torrent, L., Cabeza, M., 2018. Are sacred caves still safe havens for the endemic bats of Madagascar? Oryx 52, 271275.https://doi.org/10.1017/S0030605317001648

Flaquer, C., Torre, I., Ruiz-Jarillo, R., 2006. The value of bat-boxes in the conservation of Pipistrellus pygmaeus in wetland rice paddies. Biol. Conserv. 128, 223230.https://doi.org/10.1016/j.biocon.2005.09.030

Galan, M., Pons, J.B., Tournayre, O., Pierre, E., Leuchtmann, M., Pontier, D., Charbonnel, N., 2017. Metabarcoding for the parallel identification of several hundred predators and their preys: application to bat species diet analysis. Mol. Ecol.

Resour.https://doi.org/10.1111/1755-0998.12749

Geller, J., Meyer, C., Parker, M., Hawk, H., 2013. Redesign of PCR primers for mitochondrial cytochrome c oxidase subunit I for marine invertebrates and application in all-taxa biotic surveys. Mol. Ecol. Resour. 13, 851-861.https://doi.org/10.1111/17550998.12138 
552 Giam, X., 2017. Global biodiversity loss from tropical deforestation. Proceedings of the

553 National Academy of Sciences 114, 5775-5777.https://doi.org/10.1073/pnas.1706264114

554 Goodman, S., 2011. Les chauves-souris de Madagascar. Association Vahatra, Antananarivo.

555 Goodman, S.M., Andriafidison, D., Andrianaivoarivelo, R., Cardiff, S.G., Ifticene, E.,

556 Jenkins, R.K., Kofoky, A., Mbohoahy, T., Rakotondravony, D., Ranivo, J., 2005. The

557 distribution and conservation of bats in the dry regions of Madagascar. Anim. Conserv. 8,

558 153-165.https://doi.org/10.1017/S136794300500199X

559 Goodman, S.M., Benstead, J.P., 2005. Updated estimates of biotic diversity and endemism

560 for Madagascar. Oryx 39, 73-77.https://doi.org/10.1017/S0030605305000128

561 Goodman, S.M., Rakotondramanana, C.F., Ramasindrazana, B., Kearney, T., Monadjem, A.,

562 Schoeman, M.C., Taylor, P.J., Naughton, K., Appleton, B., 2015. An integrative approach to

563 characterize Malagasy bats of the subfamily Vespertilioninae Gray, 1821, with the

564 description of a new species of Hypsugo. Zool. J. Linn. Soc. 173, 988-

565 1018.https://doi.org/10.1111/zoj.12223

566 Goodman, S.M., Ramasindrazana, B., Maminirina, C.P., Schoeman, M.C., Appleton, B.,

567 2011. Morphological, bioacoustical, and genetic variation in Miniopterus bats from eastern

568 Madagascar, with the description of a new species. Zootaxa 2880, 1-

569 19.https://doi.org/10.1111/zoj.12223

570 Goodman, S.M., Rasoanoro, M., Ralisata, M., Ramasindrazana, B., 2014. The bats of the

571 Kianjavato-Vatovavy region, lowland eastern central Madagascar. Malagasy Nature 8, 89-

$572 \quad 102$

573 Guardiola, M., Uriz, M.J., Taberlet, P., Coissac, E., Wangensteen, O.S., Turon, X., 2015.

574 Deep-sea, deep-sequencing: metabarcoding extracellular DNA from sediments of marine

575 canyons. PLoS ONE 10, e0139633.https://doi.org/10.1371/journal.pone.0139633 
Harvey, C.A., Rakotobe, Z.L., Rao, N.S., Dave, R., Razafimahatratra, H., Rabarijohn, R.H., Rajaofara, H., MacKinnon, J.L., 2014. Extreme vulnerability of smallholder farmers to agricultural risks and climate change in Madagascar. Philosophical Transactions of the Royal Society B: Biological Sciences 369, 20130089.10.1098/rstb.2013.0089

Kari, S., Korhonen-Kurki, K., 2013. Framing local outcomes of biodiversity conservation through ecosystem services: A case study from Ranomafana, Madagascar. Ecosyst. Serv. 3, e32-e39.http://dx.doi.org/10.1016/j.ecoser.2012.12.003

Karp, D.S., Daily, G.C., 2014. Cascading effects of insectivorous birds and bats in tropical coffee plantations. Ecology 95, 1065-1074.https://doi.org/10.1890/13-1012.1

Kemp, J., López-Baucells, A., Rocha, R., Wangensteen, O.S., Andriatafika, Z., Nair, A., Cabeza, M., 2018. Metabarcoding results from the research article: "Bats as potential suppressors of multiple agricultural pests: a case study from Madagascar". Mendeley Data.https://10.17632/x43j7mv6tp.1

Kofoky, A., Andriafidison, D., Ratrimomanarivo, F., Razafimanahaka, H.J., Rakotondravony, D., Racey, P.A., Jenkins, R.K., 2006. Habitat use, roost selection and conservation of bats in Tsingy de Bemaraha National Park, Madagascar. Vertebrate Conservation and Biodiversity. Springer, pp. 213-227.

Kofoky, A.F., Randrianandrianina, F., Russ, J., Raharinantenaina, I., Cardiff, S.G., Jenkins, R.K., Racey, P.A., 2009. Forest bats of Madagascar: results of acoustic surveys. Acta Chiropt. 11, 375-392.https://doi.org/10.3161/150811009X485602

Kulikova, T., Aldebert, P., Althorpe, N., Baker, W., Bates, K., Browne, P., van den Broek, A., Cochrane, G., Duggan, K., Eberhardt, R., 2004. The EMBL nucleotide sequence database. Nucleic Acids Res. 32, D27-D30.https://doi.org/10.1093/nar/gki098 
599

600

601

602

603

604

605

606

607

608

609

610

611

612

613

614

615

616

617

618

619

620

621

622

Lee, Y.-F., McCracken, G.F., 2002. Foraging activity and food resource use of Brazilian freetailed bats, Tadarida brasiliensis (Molossidae). Ecoscience 9, 306-

313.https://doi.org/10.1080/11956860.2002.11682717

Lehmkuhl Noer, C., Dabelsteen, T., Bohmann, K., Monadjem, A., 2012. Molossid bats in an African agro-ecosystem select sugarcane fields as foraging habitat. Afr. Zool. 47, 111.https://doi.org/10.3377/004.047.0120

Leray, M., Yang, J.Y., Meyer, C.P., Mills, S.C., Agudelo, N., Ranwez, V., Boehm, J.T., Machida, R.J., 2013. A new versatile primer set targeting a short fragment of the mitochondrial COI region for metabarcoding metazoan diversity: application for characterizing coral reef fish gut contents. Front Zool 10, 34.https://doi.org/10.1186/17429994-10-34

Lindell, C., Eaton, R.A., Howard, P.H., Roels, S.M., Shave, M.E., 2018. Enhancing agricultural landscapes to increase crop pest reduction by vertebrates. Agric., Ecosyst. Environ. 257, 1-11.https://doi.org/10.1016/j.agee.2018.01.028

López-Baucells, A., Puig-Montserrat, X., Torre, I., Freixas, L., Mas, M., Arrizabalaga, A., Flaquer, C., 2017a. Bat boxes in urban non-native forests: a popular practice that should be reconsidered. Urban Ecosyst. 20, 217-225.10.1007/s11252-016-0582-9

López-Baucells, A., Rocha, R., Andriatafika, Z., Tojosoa, T., Kemp, J., Forbes, K., Cabeza, M., 2017b. Roost selection by synanthropic bats in rural Madagascar: what makes nontraditional structures so tempting? Hystrix 28, 28-35.https://doi.org/10.4404/hystrix-28.112046

Maas, B., Karp, D.S., Bumrungsri, S., Darras, K., Gonthier, D., Huang, J.C.C., Lindell, C.A., Maine, J.J., Mestre, L., Michel, N.L., 2016. Bird and bat predation services in tropical forests and agroforestry landscapes. Biological Reviews 91, 1081-1101 
623

624

625

626

627

628

629

630

631

632

633

634

635

636

637

638

639

640

641

642

643

644

645

646

647

Macías-Hernández, N., Athey, K., Tonzo, V., Wangensteen, O.S., Arnedo, M., Harwood, J.D., 2018. Molecular gut content analysis of different spider body parts. PLoS ONE 13, e0196589.https://doi.org/10.1371/journal.pone.0196589

Mahé, F., Rognes, T., Quince, C., de Vargas, C., Dunthorn, M., 2015. Swarm v2: highlyscalable and high-resolution amplicon clustering. PeerJ 3, e1420.https://doi.org/10.7717/peerj.1420

Malhi, Y., 2017. The Concept of the Anthropocene. Annu. Rev. Environ. Resour. 42, 77104.https://doi.org/10.1146/annurev-environ-102016-060854

Malmqvist, E., Jansson, S., Zhu, S., Li, W., Svanberg, K., Svanberg, S., Rydell, J., Song, Z., Bood, J., Brydegaard, M., 2018. The bat-bird-bug battle: daily flight activity of insects and their predators over a rice field revealed by high-resolution Scheimpflug Lidar. R. Soc. Open Sci. 5, 172303.https://doi.org/10.1098/rsos.172303

Martin, E.A., Viano, M., Ratsimisetra, L., Laloë, F., Carrière, S.M., 2012. Maintenance of bird functional diversity in a traditional agroecosystem of Madagascar. Agric., Ecosyst.

Environ. 149, 1-9.https://doi.org/10.1016/j.agee.2011.12.005

McConnell, W.J., Sweeney, S.P., Mulley, B., 2004. Physical and social access to land: spatiotemporal patterns of agricultural expansion in Madagascar. Agric., Ecosyst. Environ. 101, 171-184.https://doi.org/10.1016/j.agee.2003.09.012

McCracken, G.F., Gillam, E.H., Westbrook, J.K., Lee, Y.-F., Jensen, M.L., Balsley, B.B., 2008. Brazilian free-tailed bats (Tadarida brasiliensis: Molossidae, Chiroptera) at high altitude: links to migratory insect populations. Integr. Comp. Biol. 48, 107118.https://doi.org/10.1093/icb/icn033

McCracken, G.F., Westbrook, J.K., Brown, V.A., Eldridge, M., Federico, P., Kunz, T.H., 2012. Bats track and exploit changes in insect pest populations. PLoS ONE 7, e43839.https://doi.org/10.1371/journal.pone.0043839 
648

649

650

651

652

653

654

655

656

657

658

659

660

661

662

663

664

665

666

667

668

669

670

671

672

Monck-Whipp, L., Martin, A.E., Francis, C.M., Fahrig, L., 2018. Farmland heterogeneity benefits bats in agricultural landscapes. Agric., Ecosyst. Environ. 253, 131-

139.https://doi.org/10.1016/j.agee.2017.11.001

Muthayya, S., Sugimoto, J.D., Montgomery, S., Maberly, G.F., 2014. An overview of global rice production, supply, trade, and consumption. Ann. N. Y. Acad. Sci. 1324, 7-

14.https://doi.org/10.1111/nyas. 12540

Naranjo, S.E., Ellsworth, P.C., Frisvold, G.B., 2015. Economic value of biological control in integrated pest management of managed plant systems. Annu. Rev. Entomol.

60.https://doi.org/10.1146/annurev-ento-010814-021005

Neudert, R., Ganzhorn, J.U., Wätzold, F., 2017. Global benefits and local costs-The dilemma of tropical forest conservation: A review of the situation in Madagascar. Environ. Conserv. 44, 82-96.https://doi.org/10.1017/S0376892916000552

Nwilene, F.E., Nacro, S., Tamò, M., Menozzi, P., Heinrichs, E.A., Hamadoun, A., Dakouo, D., Adda, C., Togola, A., 2013. Managing Insect Pests of Rice in Africa. In: Marco C S Wopereis, David E Johnson, Nourollah Ahmadi, Eric Tollens, Jalloh, A. (Eds.), Realizing Africa's Rice Promise. CABI, p. 229.

Oerke, E.C., 2006. Crop losses to pests. The Journal of Agricultural Science 144, 3143.10.1017/S0021859605005708

Oksanen, J., Blanchet, F.G., Kindt, R., Legendre, P., Minchin, P.R., O’hara, R., Simpson, G.L., Solymos, P., Stevens, M.H.H., Wagner, H., 2013. Package ‘vegan’. Community ecology package, version 2

Parsa, S., Morse, S., Bonifacio, A., Chancellor, T.C., Condori, B., Crespo-Pérez, V., Hobbs, S.L., Kroschel, J., Ba, M.N., Rebaudo, F., 2014. Obstacles to integrated pest management adoption in developing countries. Proc. Natl. Acad. Sci. U. S. A. 111, 38893894.https://doi.org/10.1073/pnas.1312693111 
673 Peters, J., 1998. Transforming the integrated conservation and development project (ICDP)

674 approach: observations from the Ranomafana National Park Project, Madagascar. J. Agric.

675 Environ. Ethics 11, 17-47.http://dx.doi.org/10.1023/A:1007796628731

676 Puig-Montserrat, X., Torre, I., López-Baucells, A., Guerrieri, E., Monti, M.M., Ràfols-

677 García, R., Ferrer, X., Gisbert, D., Flaquer, C., 2015. Pest control service provided by bats in

678 Mediterranean rice paddies: linking agroecosystems structure to ecological functions. Mamm.

679 Biol. 80, 237-245.https://doi.org/10.1016/j.mambio.2015.03.008

680 R Development Core Team, 2017. R: A language and environment for statistical computing.

681 R Foundation for Statistical Computing, Vienna, Austria. ISBN 3-900051-07-0, URL:

682 http://www.R-project.org

683 Racey, P.A., Goodman, S.M., Jenkins, R.K., 2010. The ecology and conservation of

684 Malagasy bats. In: Fleming, T., Racey, P. (Eds.), Islands Bats: Evolution, Ecology, and

685 Conservation. . University of Chicago Press, pp. 369-404.

686 Rakotoarivelo, A.A., Ranaivoson, N., Ramilijaona, O.R., Kofoky, A.F., Racey, P.A., Jenkins,

687 R.K., 2007. Seasonal Food Habits of Five Sympatric Forest microchiropterans in Western

688 Madagascar. J. Mammal. 88, 959-966.https://doi.org/10.1644/06-MAMM-A-112R1.1

689 Randrianandrianina, F., Andriafidison, D., Kofoky, A.F., Ramilijaona, O., Ratrimomanarivo,

690 F., Racey, P.A., Jenkins, R.K., 2006. Habitat use and conservation of bats in rainforest and

691 adjacent human-modified habitats in eastern Madagascar. Acta Chiropt. 8, 429-

692 437.https://doi.org/10.3161/1733-5329(2006)8[429:HUACOB]2.0.CO;2

693 Rasolofoson, R.A., Ferraro, P.J., Jenkins, C.N., Jones, J.P.G., 2015. Effectiveness of

694 Community Forest Management at reducing deforestation in Madagascar. Biol. Conserv. 184,

695 271-277.https://doi.org/10.1016/j.biocon.2015.01.027

696 Ratnasingham, S., Hebert, P.D., 2007. BOLD: The Barcode of Life Data System

697 (http://www.barcodinglife.org). Mol. Ecol. Resour. 7, 355-364 

preliminary assessment from Moramanga, eastern Madagascar. Madag. Conserv. Dev. 5

700

701

702

703

704

705

706

707

708

709

710

711

712

713

714

715

716

717

718

719

720

721
Rocha, R., Virtanen, T., Cabeza, M., 2015. Bird assemblages in a Malagasy forest-

agricultural frontier: effects of habitat structure and forest cover. Trop. Conserv. Sci. 8, 681710.https://doi.org/10.1177/194008291500800307

Rognes, T., Flouri, T., Nichols, B., Quince, C., Mahé, F., 2016. VSEARCH: a versatile open source tool for metagenomics. PeerJ 4, e2584.https://doi.org/10.7717/peerj.2584

Russ, J., Bennett, D., 2001. The Bats of Madagascar: A Field Guide with Descriptions of Echolocation Calls. Viper Press.

Russo, D., Bosso, L., Ancillotto, L., 2018. Novel perspectives on bat insectivory highlight the value of this ecosystem service in farmland: Research frontiers and management implications. Agric., Ecosyst. Environ. 266, 31-38.https://doi.org/10.1016/j.agee.2018.07.024 Schnitzler, H.-U., Kalko, E.K.V., 2001. Echolocation by Insect-Eating Bats: We define four distinct functional groups of bats and find differences in signal structure that correlate with the typical echolocation tasks faced by each group. Bioscience 51, 557569.https://doi.org/10.1641/0006-3568(2001)051[0557:ebieb]2.0.co;2

Siegenthaler, A., Wangensteen, O.S., Benvenuto, C., Campos, J., Mariani, S., 2018. DNA metabarcoding unveils large-scale trophic variation in a widespread coastal opportunist. Mol. Ecol. in review

Sikes, R.S., Gannon, W.L., Care, A., Mammalogists, U.C.o.t.A.S.o., 2011. Guidelines of the American Society of Mammalogists for the use of wild mammals in research. J. Mammal. 92, 235-253.https://doi.org/10.1644/10-MAMM-F-355.1

Skaug, H., Fournier, D., Bolker, B., Magnusson, A., Nielsen, A., 2015. glmmADMB: generalized linear mixed models using AD model builder. R package v. 0.8. 1. 
Stenberg, J.A., 2017. A Conceptual Framework for Integrated Pest Management. Trends Plant Sci. 22, 759-769.https://doi.org/10.1016/j.tplants.2017.06.010

Styger, E., Rakotondramasy, H.M., Pfeffer, M.J., Fernandes, E.C., Bates, D.M., 2007.

Influence of slash-and-burn farming practices on fallow succession and land degradation in the rainforest region of Madagascar. Agric., Ecosyst. Environ. 119, 257269.https://doi.org/10.1016/j.agee.2006.07.012

Swift, J.F., Lance, R.F., Guan, X., Britzke, E.R., Lindsay, D.L., Edwards, C.E., 2018.

Multifaceted DNA metabarcoding: validation of a non-invasive, next-generation approach to studying bat populations. Evol. Appl. 0.https://doi.org/10.1111/eva.12644

Taylor, P., Bohmann, K., Steyn, J., Schoeman, M., Matamba, E., Zepeda-Mendoza, E., Nangammbi, T., Gilbert, M., 2013a. Bats eat pest green vegetable stinkbugs (Nezara viridula): diet analyses of seven insectivorous species of bats roosting and foraging in macadamia orchards at Levubu, Limpopo Province, South Africa. SAMAC Yearbook 21, 37 43

Taylor, P.J., Matamba, E., Steyn, J.N., Nangammbi, T., Zepeda-Mendoza, M.L., Bohmann, K., 2017. Diet determined by next generation sequencing reveals pest consumption and opportunistic foraging by bats in macadamia orchards in South Africa. Acta Chiropt. 19, 239254.https://doi.org/10.3161/15081109ACC2017.19.2.003

Taylor, P.J., Monadjem, A., Nicolaas Steyn, J., 2013b. Seasonal patterns of habitat use by insectivorous bats in a subtropical African agro-ecosystem dominated by macadamia orchards. Afr. J. Ecol. 51, 552-561.https://doi.org/10.1111/aje.12066 Torrent, L., Lopez-Baucells, A., Rocha, R., Bobrowiec, P., Meyer, C., 2018. The importance of lakes for bat conservation in Amazonian rainforests: an assessment using autonomous recorders. Remote Sens. Ecol. Conserv.https://doi.org/10.1002/rse2.83 
Verboom, B., Huitema, H., 1997. The importance of linear landscape elements for the

747

748

749

750

751

752

753

754

755

756

757

758

759

760

761

762

763

764

765

766

767

pipistrelle Pipistrellus pipistrellus and the serotine bat Eptesicus serotinus. Landscape Ecol.

\section{2, 117-125.http://dx.doi.org/10.1007/BF02698211}

Vieilledent, G., Grinand, C., Rakotomalala, F.A., Ranaivosoa, R., Rakotoarijaona, J.-R., Allnutt, T.F., Achard, F., 2018. Combining global tree cover loss data with historical national forest cover maps to look at six decades of deforestation and forest fragmentation in Madagascar. Biol. Conserv. 222, 189-197.https://doi.org/10.1016/j.biocon.2018.04.008

Wangensteen, O.S., Cebrian, E., Palacín, C., Turon, X., 2018a. Under the canopy:

Community-wide effects of invasive algae in Marine Protected Areas revealed by metabarcoding. Mar. Pollut. Bull. 127, 54-

66.https://doi.org/10.1016/j.marpolbul.2017.11.033

Wangensteen, O.S., Palacín, C., Guardiola, M., Turon, X., 2018b. DNA Metabarcoding of littoral hard-bottom communities: high diversity and database gaps revealed by two molecular markers. PeerJ 6:e4705.https://doi.org/10.7717/peerj.4705

Wangensteen, O.S., Turon, X., 2017. Metabarcoding techniques for assessing biodiversity of marine animal forests. In: Sergio Rossi, L.B., Andrea Gori, Covadonga Orejas (Ed.), Marine animal forests. The ecology of benthic biodiversity hotspots. Springer International Publishing, Switzerland, pp. 445-473.

Wanger, T.C., Darras, K., Bumrungsri, S., Tscharntke, T., Klein, A.-M., 2014. Bat pest control contributes to food security in Thailand. Biol. Conserv. 171, 220223.https://doi.org/10.1016/j.biocon.2014.01.030

Wickham, H., 2016. tidyverse: Easily install and load 'tidyverse'packages [Software]. 


\section{Click here to download Tables: Table 1 - Acoustics.xIsx}

Table 1. List of species known to occur in the region incorporating Ranomafana National Park with sonotypes created from mean peak frequency ranges from the existing literature.

\begin{tabular}{|c|c|c|c|c|c|}
\hline Sonotype & Family & Species & $\begin{array}{l}\text { Mean peak } \\
\text { frequency ranges } \\
(\mathrm{kHz})\end{array}$ & Call shape & IUCN category \\
\hline H.commersoni & Hipposideridae & Hipposideros commersoni $^{1}$ & $61.6-76.5$ & FM-CF-FM & NT \\
\hline M.goudoti & Vespertilionidae & Myotis goudoti ${ }^{1}$ & $55.3-72.1$ & FM & $\mathrm{LC}$ \\
\hline M.gle/maj & Miniopteridae & Miniopterus gleni ${ }^{1,2}$, Miniopterus majori ${ }^{1,2}$ & $42.9-50.3$ & FM-QCF & $\mathrm{LC} ; \mathrm{LC}$ \\
\hline M.manavi & Miniopteridae & Miniopterus manavi ${ }^{1,2}$ & $58.3-61.5$ & FM-QCF & $\mathrm{LC}$ \\
\hline M.aurita & Myzopodidae & Myzopoda aurita ${ }^{3}$ & 14 & FM-CF & $\mathrm{LC}$ \\
\hline O.mad/T.ful & Molossidae & Otomops madagascariensis ${ }^{3}$ Tadarida fulminans ${ }^{3}$ & $13.0-20.0$ & $\mathrm{CF}$ & $\mathrm{LC} ; \mathrm{LC}$ \\
\hline P.atrata & Emballonuridae & Paraemballonura atrata ${ }^{1}$ & $50.0-54.3$ & FM-CF & $\mathrm{LC}$ \\
\hline S.rob/M.gle & $\begin{array}{l}\text { Vespertilionidae/Min } \\
\text { ioperidae }\end{array}$ & Miniopterus gleni ${ }^{1,2}$, Scotophilus robustus ${ }^{1}$ & $38.4-42.8$ & FM-QCF & $\mathrm{LC} ; \mathrm{LC}$ \\
\hline VMil & $\begin{array}{l}\text { Vespertilionidae/Min } \\
\text { iopteridae }\end{array}$ & 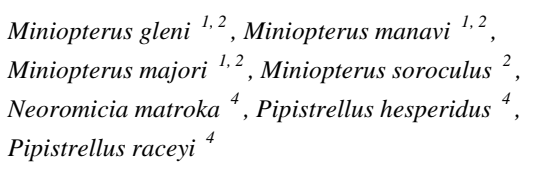 & $50.4-58.2$ & FM-QCF & $\begin{array}{l}\mathrm{LC} ; \mathrm{LC} ; \mathrm{LC} ; \mathrm{LC} ; \\
\mathrm{LC} ; \mathrm{LC} ; \mathrm{DD}\end{array}$ \\
\hline S.rob/M.jug & $\begin{array}{l}\text { Molossidae; } \\
\text { Vespertilionidae }\end{array}$ & Mormopterus jugularis ${ }^{5}$, Scotophilus robustus ${ }^{1}$ & $30.6-38.3$ & FM-QCF & $\mathrm{LC} ; \mathrm{LC}$ \\
\hline Mo1 & $\begin{array}{l}\text { Molossidae; } \\
\text { Emballonuridae }\end{array}$ & $\begin{array}{l}\text { Chaerephon atsinanana }{ }^{5} \text {, Mops leucostigma }{ }^{5} \text {, } \\
\text { Mormopterus jugularis }{ }^{5,} \text { Taphozous mauritianus }\end{array}$ & $21.0-30.5$ & FM-QCF/CF & NA; LC; LC; LC \\
\hline
\end{tabular}

Sources: Kofoky et al. 2009, 2. Ramasindrazana et al., 2011, 3. Russ and Bennett, 2001, 4. Goodman et al., 2015, 5. Release calls, 6. Fenton et al. , 1980 
Table 2. Mean bat passes $( \pm \mathrm{SD})$ per night per sonotype across each landcover type. Significant differences to continuous forest from generalised linear mixed models highlighted in bold.

\begin{tabular}{|c|c|c|c|c|c|c|}
\hline \multirow[b]{2}{*}{ Sonotype } & \multicolumn{6}{|c|}{ Landcover type } \\
\hline & $\begin{array}{c}\text { Continuous } \\
\text { forest }\end{array}$ & $\begin{array}{c}\text { Forest } \\
\text { fragment }\end{array}$ & $\begin{array}{l}\text { Secondary } \\
\text { vegetation }\end{array}$ & Irrigated rice & Hillside rice & Total \\
\hline Hipposideros commersoni & 0 & $0.04( \pm 0.2)$ & 0 & $0.03( \pm 0.2)$ & $1.09( \pm 3)$ & $0.18( \pm 1)$ \\
\hline Myzopoda aurita & 0 & 0 & $0.04( \pm 0.2)$ & $0.13( \pm 0.6)$ & $0.22( \pm 0.5)$ & $0.07( \pm 0.3)$ \\
\hline Myotis goudoti & $4.21( \pm 10)$ & $14.65( \pm 30)$ & $2.16( \pm 4)$ & $9( \pm 23)$ & $4.22( \pm 4)$ & $6.69( \pm 18)$ \\
\hline Miniopterus gleni/M.majori & $0.05( \pm 0.2)$ & $0.58( \pm 1)$ & $2.56( \pm 4)$ & $7.8( \pm 11)$ & $15.65( \pm 15)$ & $4.59( \pm 10)$ \\
\hline Miniopterus manavi & 0 & $2.85( \pm 8)$ & $0.04( \pm 0.2)$ & 0 & $0.04(+0.2)$ & $0.52( \pm 3)$ \\
\hline Mo1 & $0.12( \pm 0.5)$ & $5.5( \pm 11)$ & $20.08( \pm 38)$ & $10.67( \pm 15)$ & $98.7( \pm 131)$ & $22.04( \pm 64)$ \\
\hline Otomops madagascariensis/Tadarida fulminans & $0.07( \pm 0.5)$ & $0.92( \pm 2)$ & $0.52( \pm 1)$ & $0.17( \pm 1)$ & $23.61( \pm 100)$ & $4( \pm 40)$ \\
\hline Paraemballonura atrata & $5.4( \pm 29)$ & $0.04( \pm 0.2)$ & $1.96( \pm 7)$ & $6.87( \pm 22)$ & $2.48( \pm 6)$ & $3.71( \pm 19)$ \\
\hline Scotophilus robustus/Miniopterus gleni & 0 & 0 & $5.08( \pm 8)$ & $3.00( \pm 5)$ & $23.74( \pm 26)$ & $5.19( \pm 14)$ \\
\hline Scotophilus robustus/Mormopterus jugularis & 0 & 0 & $1.52( \pm 3)$ & $1.93( \pm 3)$ & $6.04( \pm 8)$ & $1.60( \pm 4)$ \\
\hline VMi1 & $2.84( \pm 7)$ & $7.69( \pm 15)$ & $5.84( \pm 8)$ & $48.9( \pm 100)$ & $21.3( \pm 17)$ & $16.50( \pm 49)$ \\
\hline Total & $12.72( \pm 36)$ & $32.27( \pm 55)$ & $39.80( \pm 53)$ & $\mathbf{8 8 . 5 0} \pm(\mathbf{1 2 7})$ & $197.09( \pm 228)$ & $65.1( \pm 128)$ \\
\hline
\end{tabular}


Table 3. Average relative abundance of MOTU reads per 10,000 reads for six bat species (number of samples in brackets) grouped by arthropod order. See Table A.5. for insect pest and disease vector species and genera.

\begin{tabular}{|c|c|c|c|c|c|c|c|}
\hline Order name & $\begin{array}{l}\text { C. atsinanana } \\
\text { (12) }\end{array}$ & $\begin{array}{l}\text { M. leucogaster } \\
\text { (10) }\end{array}$ & M. jugularis (9) & M. goudoti (9) & M. majori (6) & M. manavi (12) & Average \\
\hline Araneae & 0 & 0 & 0 & 27.34 & 0 & 0 & 4.56 \\
\hline Astigmata & 0 & 0 & 0.3 & 0 & 1.68 & 2.54 & 0.76 \\
\hline Blattodea & 2.7 & 33.16 & 134.95 & 19.62 & 307.45 & 325.05 & 137.15 \\
\hline Coleoptera & 1095.78 & 1708.65 & 1845.63 & 891.49 & 112.43 & 672.35 & 1054.39 \\
\hline Dermaptera & 0 & 0 & 19.36 & 0 & 0 & 0 & 3.23 \\
\hline Diptera & 64.56 & 94.34 & 834.68 & 163.94 & 137.09 & 208.7 & 250.55 \\
\hline Ephemeroptera & 625.26 & 17.09 & 1053.68 & 67.67 & 76.4 & 44.52 & 314.1 \\
\hline Hemiptera & 1.42 & 17.23 & 18.86 & 30.32 & 1933.65 & 661.81 & 443.88 \\
\hline Hymenoptera & 0.05 & 1.3 & 0.1 & 352.68 & 104.67 & 708.29 & 194.51 \\
\hline Lepidoptera & 138.94 & 63.06 & 414.78 & 324.2 & 2351.33 & 846.68 & 689.83 \\
\hline Mesostigmata & 0 & 0.8 & 0 & 1.28 & 0 & 26.12 & 4.7 \\
\hline Neuroptera & 0 & 0 & 3.96 & 0 & 0 & 0.69 & 0.78 \\
\hline Odonata & 0.32 & 0 & 0 & 0 & 0 & 0 & 0.05 \\
\hline Orthoptera & 3.23 & 2.68 & 3.35 & 0 & 0 & 0 & 1.54 \\
\hline Sarcoptiformes & 0.66 & 14.46 & 2.57 & 72.57 & 1.8 & 8.05 & 16.69 \\
\hline Siphonaptera & 0.31 & 0 & 0 & 0 & 0 & 0 & 0.05 \\
\hline Symphypleona & 0 & 0 & 0 & 1.74 & 0 & 0 & 0.29 \\
\hline Trichoptera & 3.05 & 0.02 & 0 & 3.51 & 10.22 & 0 & 2.8 \\
\hline Trombidiformes & 0.5 & 0.33 & 0 & 0.2 & 185.73 & 2.67 & 31.57 \\
\hline Total & 1936.78 & 1953.11 & 4332.25 & 1956.53 & 5222.45 & 3507.48 & \\
\hline
\end{tabular}




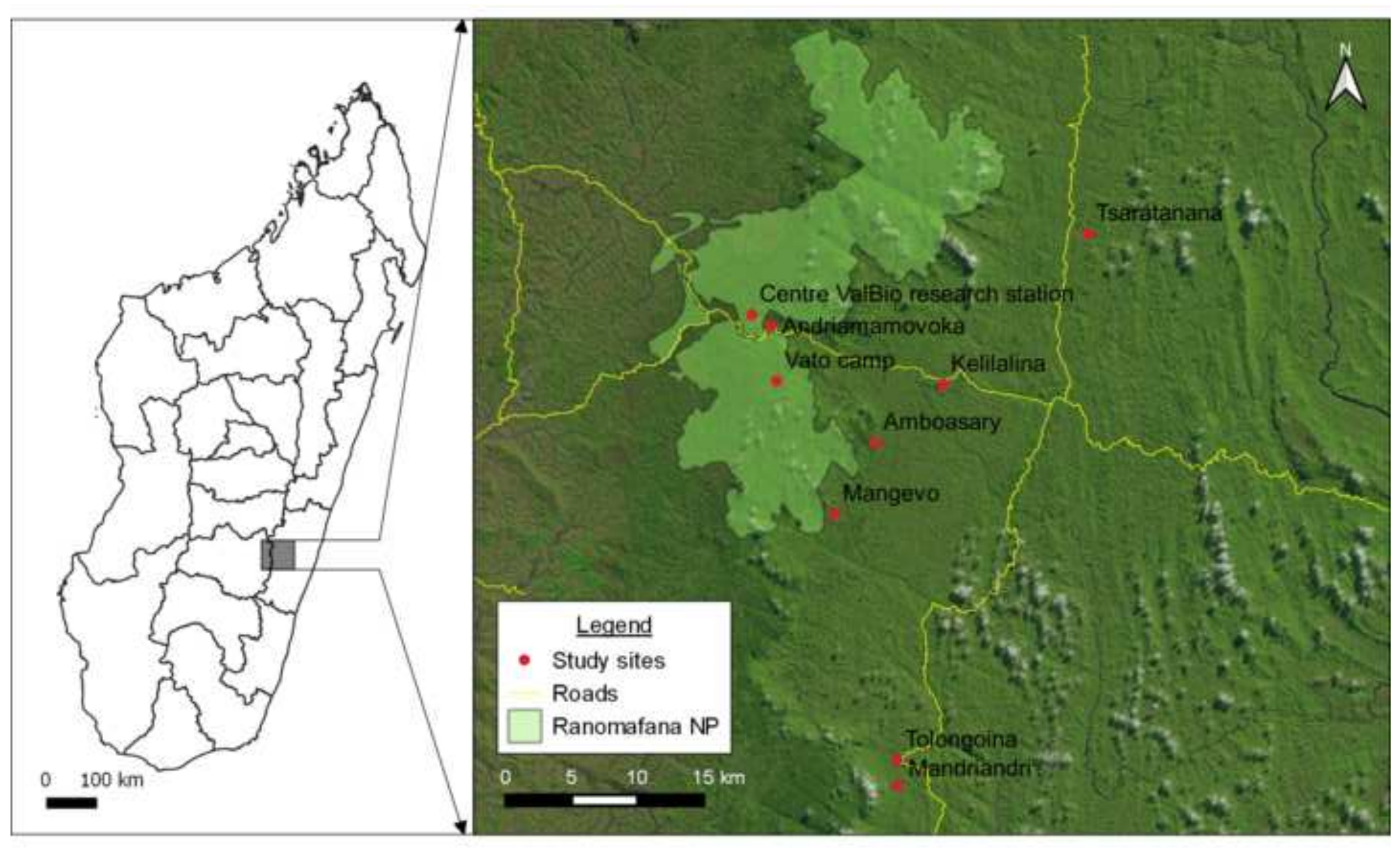




\section{n bat activity}

Click here to download high resolution image

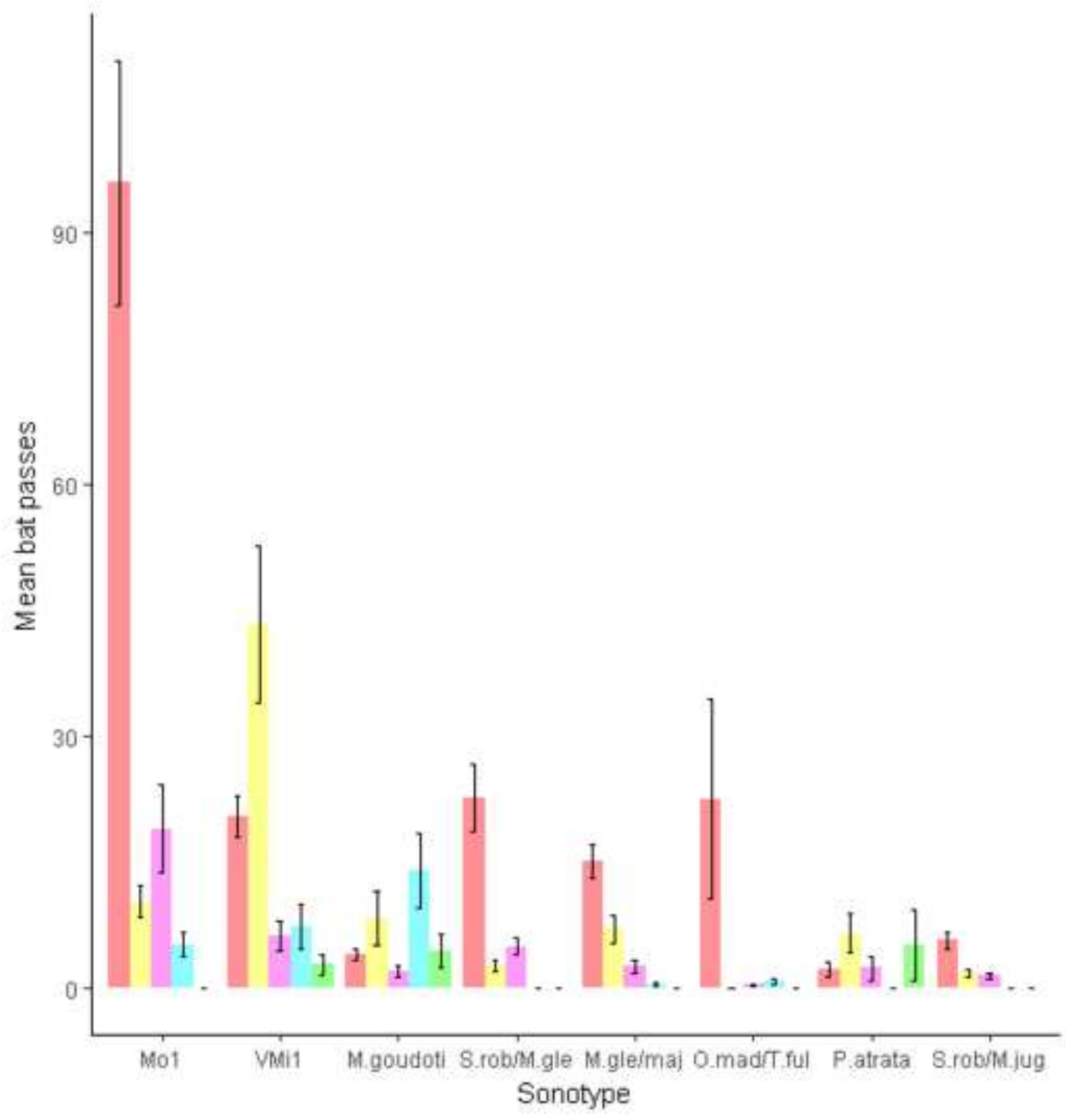

Landcover type

Hillside rice

Irrigated rice

Secondary vegetation

Forest fragment

Continuous forest

Sonotype 


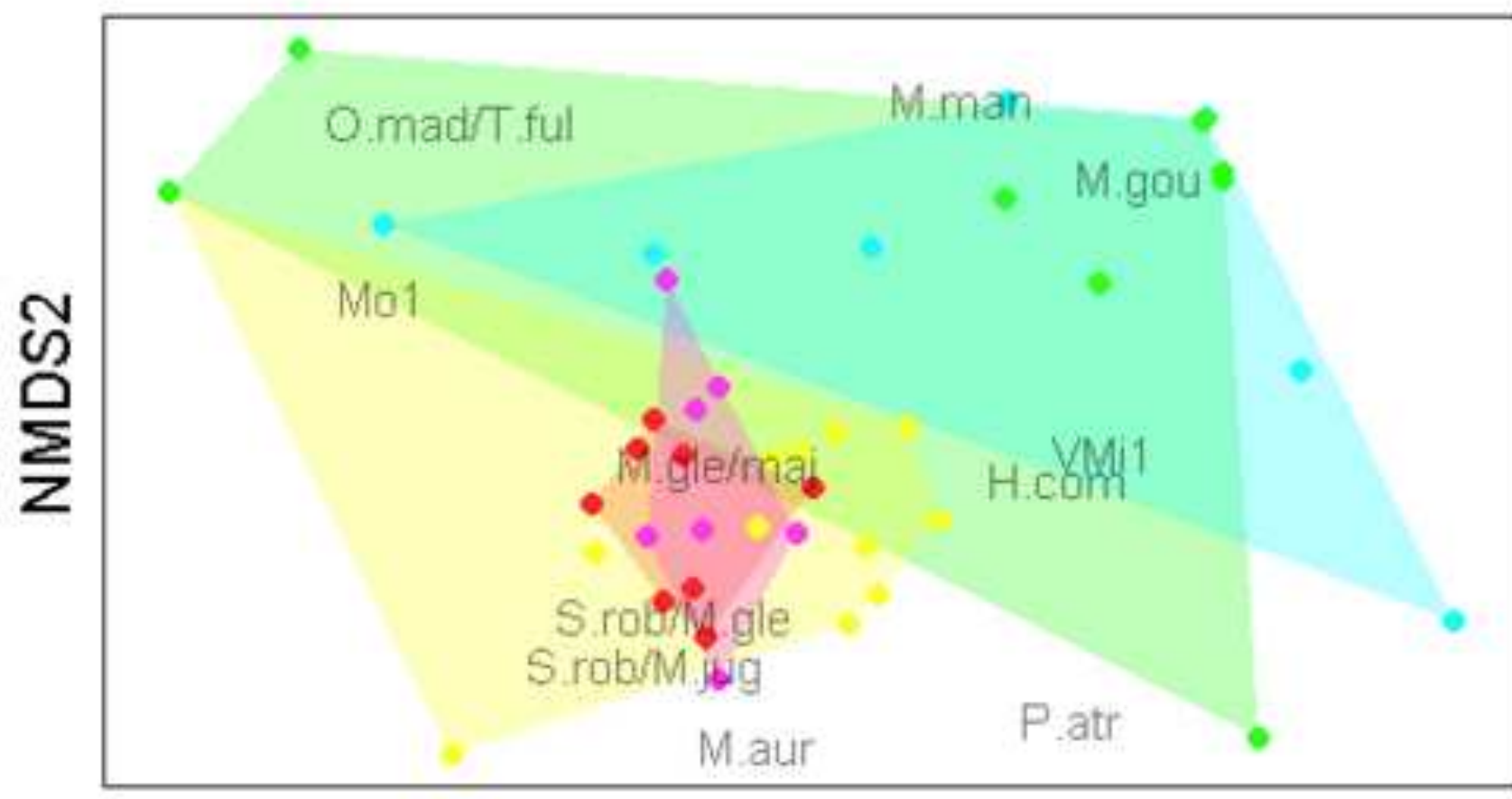

\section{Landcover}

- Hillside rice Irrigated rice

- Secondary vegetation

\section{Forest fragment}

Continuous forest

\section{NMDS1}



Supplementary Material for publication online only
Click here to download Supplementary Material for

Click here to download Supplementary Material for publication online only: Kemp et al_supplementary material.docx 